\title{
Antibiotic Resistance of Bacterial Isolates from HIV Positive Patients with Urinary Tract Infection (UTI) in Portharcourt, Nigeria
}

\section{Tchounga S Kemajou', Anslem O Ajugwo ${ }^{2 *}$, Cyprian E Oshoma ${ }^{1}$ and Enabulele $\mathrm{OI}^{1}$}

${ }^{1}$ Department of Microbiology, Faculty of Life Sciences, University of Benin, Benin City, Nigeria

${ }^{2}$ Department of Medical Laboratory Science, Madonna University Elele, Nigeria

\begin{abstract}
This study was carried out to evaluate the prevalence of HIV associated Urinary tract infections (UTI) in Portharcourt Metropolis. 286 urine samples were collected from 246 HIV seropositive and 40 HIV seronegative individuals. Mid stream urine samples collected from these individuals were processed by standard protocols to examine for bacterial opportunistic pathogens. Antibiotic susceptibility testing was performed using Kirby-Bauer's disc diffusion method. Out of 246 HIV individuals examined, $141(57.3 \%)$ urine samples yielded growth of bacterial isolates, with age group 24-30 years recording the highest number of isolates $45(32.9 \%)$, while those above 44 years old had the least with $11(7.8 \%)$. About $24(60 \%)$ samples out of 40 seronegative individuals yielded growth of bacteria and age group 17-23 years recorded the highest number of isolates $7(29.1 \%)$, while those above 44 years had the least $1(4.1 \%)$. Female individuals recorded the highest number of bacterial isolates than males. A total of 165 bacteria were identified and grouped into four genera out of which Staphylococcus aureus had the highest percentage of occurrence $49(29.7 \%)$, followed by Escherichia coli 47 (28.5\%), Pseudomonas aeruginosa 46 (27.9\%) and Klebsiella pneumoniae $23(13.9 \%)$. Out of 111 bacterial isolates that exhibited multidrug resistance, HIV Seropositive individuals had $103(92.8 \%)$ and HIV seronegative individuals $8(7.2 \%)$. Over all, Staphylococcus aureus recorded the highest number of multidrug resistant bacteria 36 (32.4\%), followed by Pseudomonas aeruginosa 34 (30.6\%). The high levels of multidrug resistance in HIV seropositive individuals are a serious public Health concern. Therefore appropriate health education to reduce selfmedication and drug abuse is very imperative and desirous.
\end{abstract}

Keywords: HIV; UTI; MDR; Drug abuse; Portharcourt

\section{Introduction}

Human Immunodeficiency Virus (HIV) is a lentivirus that causes immunodeficiency syndrome $[1,2]$ a condition in humans in which progressive failure of the immune system allows life threatening opportunistic infections to thrive. Most untreated people infected with HIV-1 eventually develop AIDS [3]. These individuals usually die of opportunistic infections or malignancies associated with progressive failure of the immune system. HIV infects vital cells in the human immune system such as helper $\mathrm{T}$ cells (specifically $\mathrm{CD} 4^{+} \mathrm{T}$ cells), macrophages and dendritic cells [4]. HIV infection leads to low levels of $\mathrm{CD}^{+} \mathrm{T}$ cells through three main mechanisms. First, direct viral killing of the infected cells; second, increased rate of apoptosis in infected cells; and third, killing of infected $\mathrm{CD} 4^{+}$cells by $\mathrm{CD} 8$ cytotoxic lymphocytes that recognize infected cells. When $\mathrm{CD}^{+}$cells number decline below a critical level, cell mediated immunity is lost and the body becomes progressively more susceptible to opportunistic infections. Urinary tract infection (UTI) is one of the significant illnesses that cause burden. It is the most common nosocomial infection, but an important source of morbidity as well [5]. UTI is one of the most common bacterial infection and cause of morbidity and hospitalization in HIV positive individuals [6]. HIV disease is associated with a variety of renal syndromes in patients with low $\mathrm{CD} 4^{+}$cell counts, causing neurologic complications which lead to urinary stasis and ultimately infection $[7,8]$. Once a patient's $\mathrm{CD} 4^{+} \mathrm{T}$ cell count falls below 200 cells $/ \mathrm{mm}^{3}$, the individual is then at risk of a variety of opportunistic infections. The infectious organisms may include fungi, protozoa, viruses and bacteria. The most predominant causative organisms are encapsulated bacteria notably: Streptococcus pneumoniae and Haemophilus influenzae, but non-typhoidal Salmonella, Staphylococcus aureus and Pseudomonas aeruginosa have also been implicated [9]. Among opportunistic infections, UTI accounts for $60 \%$ of AIDS defining illnesses [10]. The prevalence of data on the frequency of UTIs in HIV infected patients is scanty and not updated in Port Harcourt, Rivers State. Urinary tract infections account for a significant proportion of patient's daily hospital visits in HIV patients [11]. UTIs also account for a large proportion of antibacterial drug consumption [6]. Resistance to commonly prescribed antibiotics for UTI is an expanding global problem both in developed as well as developing countries [12]. Due to the wide spread and injudicious use of antibiotic, we are encountered with more resistance patterns to common antibiotics [13]. UTI became quite alarming as isolated uropathogens exhibited high percentage resistance to almost all antibiotics [14]. These multidrug resistant (MDR) pathogens are relentlessly multiplying in HIV patients and thus, becoming an important circulating source of infection especially in Port Harcourt Metropolis.

The present study was carried out to evaluate the prevalence of various bacterial isolates from HIV seropositive and HIV seronegative urinary tract infected individuals attending University of Port Harcourt Teaching Hospital (UPTH), Port Harcourt Rivers State.

*Corresponding author: Anslem O Ajugwo, Department of Medical Laboratory Science, Madonna University Elele, Nigeria, Tel: +2348033343128; E-mail: slemjugwo@yahoo.com

Received April 27, 2016; Accepted June 23, 2016; Published June 30, 2016

Citation: Kemajou TS, Ajugwo AO, Oshoma CE, Enabulele Ol (2016) Antibiotic Resistance of Bacterial Isolates from HIV Positive Patients with Urinary Tract Infection (UTI) in Portharcourt, Nigeria. J AIDS Clin Res 7: 594. doi:10.4172/2155-6113.1000594

Copyright: (c) 2016 Kemajou TS, et al. This is an open-access article distributed under the terms of the Creative Commons Attribution License, which permits unrestricted use, distribution, and reproduction in any medium, provided the original author and source are credited. 


\section{Materials and Methods}

\section{Sample collection and processing}

A total of 286 individuals attending Clinic at University of Port Harcourt Teaching Hospital (UPTH) during the period of February 2015 to November 2015 were used for this study. They consisted of 246 seropositive individuals and 40 seronegative individuals. The HIV seropositive individuals included: 111 males and 135 females; while the HIV seronegative individuals included: 25 females and 15 males. Ethical clearance was obtained from the Ethical Review Board.

Mid stream urine samples were collected in sterile containers by taking all precautions to avoid contamination. The urine samples were immediately taken to the laboratory and cultured within $30 \mathrm{~min}$ of collection on MacConkey and Cystein lactose electrolyte deficient (CLED) agar. The plates were incubated at $37^{\circ} \mathrm{C}$ for $24 \mathrm{~h}$, while microscopy was also carried out following standard protocols. In case of delay, the samples were kept at $4^{\circ} \mathrm{C}$ in the refrigerator and cultured within $6 \mathrm{~h}$. The isolates were identified using standard biochemical reactions [15].

\section{Antibiotic sensitivity test}

The isolates were tested for their susceptibility to commonly prescribed antibiotics using Kirby Bauer disc diffusion method $[16,17]$. Antibiotics used for the isolates were Cotrimoxazole $(23.75$ $\mu \mathrm{g})$, Ciprofloxacin $(5 \mu \mathrm{g})$, gentamicin $(10 \mu \mathrm{g})$, Ceftazidine $(30 \mu \mathrm{g})$, Erythromycin $(15 \mu \mathrm{g})$, Ofloxacin $(5 \mu \mathrm{g})$, Oxacillin $(1 \mu \mathrm{g})$, Ceftriaxone $(30 \mu \mathrm{g})$, Streptomycin $(10 \mu \mathrm{g})$, Tetracycline $(25 \mu \mathrm{g})$, Amoxicillin/ Clavulanic acid $(20 \mu \mathrm{g})$, Chloramphenicol $(30 \mu \mathrm{g})$, Nitrofurantoin $(30 \mu \mathrm{g})$ [18]. Isolates showing resistance to three or more categories of antibiotics were considered as multidrug resistant bacteria [19].

\section{Results}

Out of the 246 HIV seropositve individuals who were analyzed during this study, 135 (54.9\%) were females, while 111 (45.1\%) were males. Out of $40 \mathrm{HIV}$ seronegative individuals, 25 (62.5\%) were females, and 15 (37.5\%) were male. The age group ranged 17 years to 44 years and above as shown in Table 1. About 141 (57.3\%) urine sample collected from HIV seropositve individuals yielded growth of bacterial isolates. Age group 24-30 years had the highest number of bacterial isolates 45 (32.9\%), followed by age group $17-35$ years $37(26.2 \%)$, while those above 44 years recorded the least 11 (7.8\%). Female individuals were more affected than male as shown in Table 2. About 24 (60\%) urine sample from HIV seronegative individuals yielded growth of bacterial, with age group 17-23 years recording the highest frequency of occurrence 7 (29.1\%), followed by age group 24-30 years and $31-37$ years $6(25 \%)$ each. Those above 44 years old had the least $1(4.1 \%)$ as shown in Table 3. A total of 165 bacteria isolates were identified and grouped into 4 genera out of which Staphylococcus aereus had the highest percentage of occurrence 49 (29.7\%) followed by Escherichia coli 47 (28.5\%), Pseudomonas aeruginosa 46 (27.9\%) and Klebsiella pneumoniae 23(13.9\%) as shown in Table 4. Identified isolates were tested against commonly prescribed antibiotics, and isolates from HIV seropositive individuals exhibited high levels of multidrug resistance ability with S. aureus 32 (31.1\%), E. coli 31 (30.1\%), P. aeruginosa 30 (29.1\%) and K. pneumonia 10 (9.7\%); while from HIV seronegative individuals, E. coli and K. pneumoniae did not show any MDR ability as shown in Tables 5 and 6.

\section{Discussion}

It was observed that patients with immunosuppression have very high chances of developing bacteria. UTI in HIV-positive patients tends to recur, requiring longer treatment and it is suggested that treatment should be culture-specific [20].

In this study, $246 \mathrm{HIV}$ seropositive and $40 \mathrm{HIV}$ seronegative individuals were analysed. 141 (85.5\%) bacterial isolates were isolated from HIV seropositive and 24 (14.5\%) from HIV seronegative individuals. These findings are in accordance with another study where bacteria were isolated from HIV reactive patients and HIV nonreactive patients. Four bacterial genera including Staphylococcus aureus 49 (29.7\%), Escherichia coli 47 (28.7\%), Pseudomonas aeruginosa 46 (27.9\%) and Klebsiella pneumoniae 23 (13.9\%) were isolated. This observation correlates with earlier findings [21], and in contrast with Enterococcus species reported as the most common urinary isolates [22]. Staphylococcus aureus had the highest percentage of occurrence, and it had earlier been identified as the most common uropathogen [23], though in contrast to a study where E. coli had the highest percentage of occurrence 27 (36.4\%) [5]. Colonization with Staphylococcus aureus has been reported to be a risk factor for subsequent clinical infection in HIV positive patients [24,25]. Globally, Staphylococcus aureus infections have been reported to be an important cause of morbidity and mortality [26]. HIV positive individuals are at increased risk of opportunistic and common bacterial infections [27,28]. Results also revealed that that HIV seropositive individuals exhibited significant levels of bacterial colonization with multiple drug resistant $S$. aureus 32 (31.1\%), E. coli 31 (30.1\%), P. aeruginosa 30 (29.1\%) and $K$. pneumonia 10 (9.7\%) which is similar with earlier findings [21]. This further confirms that immunocompromised status like HIV is a hot spot for multiple drug resistant pathogens to multiply relentlessly and become source of infection to other healthy population and this situation raises serious health concern. Most of the isolates were resistant to oxacillin, tetracycline, chloramphenicol and ampicillin. This emergence of multiple drug resistance in the management of UTI among HIV individuals is a serious public health problem particularly in the developing world where aside from high level of poverty, ignorance and poor hygiene practices, there is a high prevalence of sub-standard and spurious drugs of questionable quality in circulation [29]. This high MDR antibiotic level also suggests a very high resistance gene pool due perhaps to gross misuse and inappropriate usage of antibacterial agents. The upsurge in antibiotic resistance noticed in this study is in agreement with earlier work [30], where antibiotic abuse and high prevalence of self medication with antibiotics were identified as being responsible for the selection of antibiotic resistant bacterial strains. The presence of multiple drug resistant bacteria in the urine of HIV seropositive individuals will significantly increase the risk of super imposed opportunistic infections which may be less susceptible to antibiotic treatments. Urinary tract infection in HIV

\begin{tabular}{|c|c|c|c|c|c|c|}
\hline & \multicolumn{2}{|c|}{$\begin{array}{c}\text { HIV Seropositive } \\
\text { group }\end{array}$} & \multicolumn{2}{c|}{$\begin{array}{c}\text { HIV Seronegative } \\
\text { group }\end{array}$} & \multicolumn{2}{c|}{$\begin{array}{c}\text { Total numbers of } \\
\text { cases analyzed }\end{array}$} \\
\hline Year & Female & Male & Female & Male & Female & Male \\
\hline $17-23$ & 15 & 10 & 5 & 1 & 20 & 11 \\
\hline $24-30$ & 29 & 21 & 7 & 5 & 36 & 26 \\
\hline $31-37$ & 48 & 39 & 6 & 4 & 54 & 43 \\
\hline $38-44$ & 35 & 30 & 4 & 3 & 39 & 33 \\
\hline$>44$ & 8 & 11 & 3 & 2 & 11 & 13 \\
\hline Total & 135 & 111 & 25 & 15 & 160 & 126 \\
\hline
\end{tabular}

Table 1: Age and sex distribution of HIV seropositive and HIV seronegative patients with UTI. 
Citation: Kemajou TS, Ajugwo AO, Oshoma CE, Enabulele OI (2016) Antibiotic Resistance of Bacterial Isolates from HIV Positive Patients with Urinary Tract Infection (UTI) in Portharcourt, Nigeria. J AIDS Clin Res 7: 594. doi:10.4172/2155-6113.1000594

Page 3 of 4

\begin{tabular}{|c|c|c|c|c|c|c|c|c|c|c|c|}
\hline \multicolumn{3}{|c|}{$\begin{array}{c}\text { Escherichia } \\
\text { coli }\end{array}$} & \multicolumn{2}{|c|}{ Klebsiella pneumoniae } & \multicolumn{2}{|c|}{ Pseudomonas aeruginosa } & \multicolumn{2}{|c|}{$\begin{array}{c}\text { Staphylococcus } \\
\text { aureus }\end{array}$} & \multicolumn{3}{|c|}{ Total } \\
\hline Age (yrs) & Female & Male & Female & Male & Female & Male & Female & Male & Female & Male & Total \\
\hline $17-23$ & 7 & 2 & 4 & 1 & 9 & 2 & 7 & 5 & 27 & 10 & 37 \\
\hline $24-30$ & 9 & 4 & 6 & - & 11 & 4 & 8 & 3 & 34 & 11 & 45 \\
\hline $31-37$ & 5 & 5 & 3 & - & 7 & 1 & 4 & 4 & 19 & 10 & 29 \\
\hline $38-44$ & 5 & 2 & 2 & 2 & 3 & - & 3 & 2 & 13 & 6 & 19 \\
\hline$>44$ & 2 & 1 & 1 & 1 & 2 & - & 2 & 2 & 7 & 4 & 11 \\
\hline Total & 28 & 14 & 16 & 4 & 32 & 7 & 24 & 16 & 100 & 41 & 141 \\
\hline
\end{tabular}

Table 2: Age and sex distribution of HIV seropositive urinary tract infected patients.

\begin{tabular}{|c|c|c|c|c|c|c|c|c|c|c|c|}
\hline \multicolumn{3}{|c|}{$\begin{array}{c}\text { Escherichia } \\
\text { coli }\end{array}$} & \multicolumn{2}{|c|}{ Klebsiella pneumoniae } & \multicolumn{2}{|c|}{$\begin{array}{c}\text { Pseudomonas } \\
\text { aeruginosa }\end{array}$} & \multicolumn{2}{|c|}{ Staphylococcus aureus } & \multicolumn{3}{|c|}{ Total } \\
\hline Age & Female & Male & Female & Male & Female & Male & Female & Male & Female & Male & Total \\
\hline $17-23$ & - & 1 & 1 & - & 1 & - & 2 & 2 & 4 & 3 & 7 \\
\hline $24-30$ & 2 & - & 1 & - & 1 & - & 2 & - & 6 & - & 6 \\
\hline $31-37$ & 1 & - & 1 & - & 2 & 1 & 1 & - & 5 & 1 & 6 \\
\hline $38-44$ & 1 & - & - & - & 1 & - & 1 & 1 & 3 & 1 & 4 \\
\hline$>44$ & - & - & - & - & 1 & - & - & - & 1 & - & 1 \\
\hline Total & 4 & 1 & 3 & - & 6 & 1 & 6 & 3 & 19 & 5 & 24 \\
\hline
\end{tabular}

Table 3: Age and sex distribution of HIV seronegative urinary tract infected patients.

\begin{tabular}{|c|c|c|}
\hline Bacterial Isolates & HIV Seropositve $\mathbf{( n = 2 4 6 )}$ With culture growth & HIV seronegative $(\mathbf{n = 4 0 )}$ With culture growth \\
\hline Escherichia coli & 42 & 5 \\
\hline Klebsiella Pneumoniae & 20 \\
\hline P. aeruginosa & 39 & 3 \\
\hline S. aureus & 40 & 7 \\
\hline Total & 141 & 9 \\
\hline
\end{tabular}

Table 4: Distribution of bacterial isolates among HIV seropositive and HIV seronegative UTI patients.

\begin{tabular}{|c|c|c|c|c|c|c|c|c|}
\hline \multirow{2}{*}{$\begin{array}{c}\text { Antibiotics } \\
\text { OXA }\end{array}$} & \multicolumn{2}{|c|}{$\begin{array}{c}\text { Escherichia coli } \\
\text { HIV+n=42 (\%) HIV-n=5 (\%) }\end{array}$} & \multicolumn{2}{|c|}{$\begin{array}{c}\text { Klebsiella pneumoniae } \\
\text { HIV+n=20 (\%) HIV-n=3 (\%) }\end{array}$} & \multicolumn{2}{|c|}{$\begin{array}{c}\text { Pseudomonas pneumoniae } \\
\text { HIV+n=39 (\%) HIV-n=7 (\%) }\end{array}$} & \multicolumn{2}{|c|}{$\begin{array}{l}\text { Staphylococcus aureus } \\
\text { HIV+n=40 (\%) HIV-n=9 (\%) }\end{array}$} \\
\hline & $39(92.81)$ & $2(40.0)$ & $13(65.0)$ & 1 (33.3) & 37 (94.9) & $5(71.4)$ & $38(95.0)$ & $4(44.4)$ \\
\hline GEN & $3(7.1)$ & $0(0.0)$ & $4(20.0)$ & $0(0.0)$ & $10(25.6)$ & $3(42.9$ & $13(32.5)$ & $3(33.3)$ \\
\hline CAZ. & $40(95.2)$ & $1(20.0)$ & $10(50.0)$ & $2(66.6)$ & $31(79.5)$ & $4(57.1)$ & $32(80.0)$ & $4(44.4)$ \\
\hline AMC & $15(35.7)$ & $1(20.0)$ & $8(40.0)$ & $1(33.3)$ & $29(74.3)$ & $4(57.1)$ & $25(62.5)$ & $3(33.3)$ \\
\hline STR & $10(23.8)$ & $2(40.0)$ & $12(60.0)$ & $1(33.3)$ & $19(48.7)$ & $3(42.9)$ & 27 (67.5) & $3(33.3)$ \\
\hline CRO. & $29(69.0)$ & $3(00.0)$ & $12(60.0)$ & $1(33.3)$ & $30(76.9)$ & $3(42.9)$ & $16(40.0)$ & $2(22.2)$ \\
\hline OFX & $1(2.4)$ & $1(20.0)$ & $13(15.0)$ & $0(0.0)$ & $8(20.5)$ & $2(28.6)$ & $4(10.0)$ & $1(11.1)$ \\
\hline ERY & $18(42.9)$ & $3(60.0)$ & $2(10.0)$ & 1 (33.3) & $31(79.5)$ & $5(71.4)$ & $25(62.5)$ & $4(44.4)$ \\
\hline TET & $21(50.0)$ & $1(20.0)$ & $9(45.0)$ & $1(33.3)$ & $38(97.4)$ & $6(85.7)$ & $36(90.0)$ & $4(44.4)$ \\
\hline $\mathrm{CHL}$ & $31(73.8)$ & $2(40.0)$ & $12(60.0)$ & $2(66.6)$ & $38(97.4)$ & $6(85.7)$ & $28(70.0)$ & $4(44.4)$ \\
\hline AMP. & $37(88.0)$ & $4(80.0)$ & $12(60.0)$ & $1(33.3)$ & $30(76.9)$ & $5(71.4)$ & $26(65.0)$ & $3(33.3)$ \\
\hline CIP & $7(16.7)$ & $1(20.0)$ & $5(25.0)$ & $0(0.0)$ & $10(25.6)$ & $3(42.9)$ & $9(22.5)$ & $2(22.2)$ \\
\hline NIT & $19(45.2)$ & $2(40.0)$ & $4(20.0)$ & $0(0.0)$ & $30(76.9)$ & $4(57.1)$ & 15 (37.5) & 2.(22.2) \\
\hline СOT & $18(42.9)$ & $2(40.0)$ & $13(65.0)$ & $1(33.3)$ & $37(94.9)$ & $6(85.7)$ & $30(75.0)$ & $4(44.4)$ \\
\hline
\end{tabular}

OXA=Oxacillin, GEN=Gentamicin, CAZ=Ceftazidine, AMC=Amoxycillin, STR=Streptomycin, CRO=Ceftriaxone, OFX=Ofloxacin, ERY=Erythromycin, TET=Tetracycline $\mathrm{CHL}=$ Chloramphenicol, $\mathrm{AMP}=\mathrm{Ampicillin}, \mathrm{CIP}=$ Ciprofloxacin, NIT=Nitrofurantoin, COT=Cotrimoxazole

Table 5: Antibiotic resistance profile of bacterial isolates from HIV seropositive and seronegative urinary tract infected patients.

\begin{tabular}{|c|c|c|c|c|}
\hline \multirow{2}{*}{ Isolates } & \multicolumn{2}{|c|}{ HIV Seropositive Individuals } & \multicolumn{2}{|c|}{ HIV Seronegative Individuals } \\
\hline & Total number of Isolates examined & MDR isolates & Total number of Isolates examined & MDR Isolates \\
\hline Escherichia coli & 42 & 31 & 5 & 0 \\
\hline Klebsiella pneumoniae & 20 & 10 & 3 & 0 \\
\hline Pseudomonas aeruginosa & 39 & 30 & 7 & 4 \\
\hline Staphylococcus aureus & 40 & 32 & 9 & 4 \\
\hline Total & 141 & 103 & 24 & 8 \\
\hline
\end{tabular}

Table 6: Frequency of occurrence of multi drug resistant (MDR) bacteria isolated from HIV seropositive and seronegative urinary tract infected individuals in portharcourt metropolis. 
Citation: Kemajou TS, Ajugwo AO, Oshoma CE, Enabulele OI (2016) Antibiotic Resistance of Bacterial Isolates from HIV Positive Patients with Urinary Tract Infection (UTI) in Portharcourt, Nigeria. J AIDS Clin Res 7: 594. doi:10.4172/2155-6113.1000594

Page 4 of 4

positive patients tend to recur, requiring longer treatments and it is suggested that treatment should be culture-specific [20]. According to the findings of this study, the need for appropriate health education to reduce self-medication and drug abuse is very imperative and desirous. These results also suggest the need for further investigation into the mechanism of drug resistance among immune compromised individuals.

\section{References}

1. Weiss RA (1993) How does HIV cause AIDS? Science 260: 1273-1279.

2. Douek DC, Roederer M, Koup RA (2009) Emerging concepts in the immunopathogenesis of AIDS. Annu Rev Med 60: 471-484.

3. Miguelles S, Connors M (2010) Long term Non-progressive disease among untreated HIV-infected individuals: Clinical implications of understanding immune control of HIV. Journal of the American Medical Assoc. 304: 194-201.

4. Cunningham AL, Donaghy H, Harman AN, Kim M, Turville SG (2010) Manipulation of dendritic cell function by viruses. Curr Opin Microbiol 13: 524529

5. Deokar S, Badhankar MG (2009) Studies on emergence of drug resistance in HIV associated bacterial urinary tract infections. Am J Inf Dis 5: 183-187.

6. Iweriobor BC, Obi CL, Akenyemi O (2012) Uropathogens isolated from HIV infected patients from Limpopo Province, South Africa. Afr J Biotech 11: 1059810604

7. Rashmi KS, Ravi Kumar KI, Rhagyashree HN (2013) Asymptomatic bacteriuria in HIV/AIDS patients occurrence and risk associated with low CD4 counts. JEMDS. 2: $3358-3360$

8. Staiman VR, Lowe FC (2004) Urologic problems in patients with acquired immunodeficiency syndrome. Scientific World Journal 4 Suppl 1: 427-437.

9. Hidron Al, Kempker R, Moanna A, Rimland D (2010) Methicillin-resistant Staphylococcus aureus in HIV-infected patients. Infect Drug Resist 3: 73-86.

10. De Pinho AM, Lopes GS, Ramos-Filho CF, Santos Oda R, De Oliveira MP, et al. (1994) Urinary tract infection in men with AIDS. Genitourin Med 70: 30-34.

11. Iroha I, Nwakeze E, Ejikeugwu C, Oji A, Udu-lbiam E, et al. (2013) Frequency and antibiogram of uropathogens isolated from urine samples of HIV infected patients on ART. Am J Biosc 1: 50-53.

12. Biradar SK, Srikanth, Doddamanni PK (2013) Prevalence and antibiogram of uropathogens in a tertiary case hospital. World Journal of Pharmaceutical Research 2: 1534-1543.

13. Frank-Peterside N, Chukwugozim R, Okerentugha PO (2013) HIV-1-2 coinfection with multidrug resistant (MDR) uropathogens in Portharcourt, Nigeria. Nature and Science 11: 11- 20.

14. Murugan K, Savitha T, Vasanilu S (2012) Retrospective study of antibiotic resistance among uropathogens from Teaching Hospital, Tamil Nadu, India. Asia Pacific Journal of Tropical Diseases. 1808: 60082-60086.

15. Collec GJ, Fraser AG, Marmion BP (1996) Mackie and MacCartney's practical medical microbiology (14 ${ }^{\text {th }}$ Edn.) Churchill Livingstone, New York.
16. Ericcson HM (1971) The agar dilution method. Acta Pathol Microbiol Scand 217: 11

17. Clinical and Laboratory Standards Institute (2007) Performance standards for antimicrobial disc susceptibility test (9thEdn) Approved Standard M2-A9, Wayne PA. Documents M100-S17

18. Wayne PA, CLSI (2013) Performance standard for antimicrobial susceptibility testing; twenty-third informational supplements. Clinical and Standard Institute M100 - S23.

19. Magiorakos AP, Srinivasan A, Carey RB, Carmeli Y, Falagas ME, (2012) Multidrug resistant, extensively drug-resistant and Pan drug resistant bacteria: An International expert proposal for interim standard definitions for acquired resistance. Clin Microbiol Infect 18: 268-281.

20. Widmer TA, Theron G, Grove D (2010) Prevalence and risks of asymptomatic bacteriuria among HIV positive pregnant women. South Afr J Epidemiol Infect 25: 28-32.

21. Adeyemi FM, Akonai KA, Oyemiyi TT, Kassim OO, Blessing IE, et al. (2015) Molecular characterization and antibiotic resistance profiles of bacterial isolates cultured from HIV seropositive patients. Archives of Clinical Microbiology 6 : $1-12$.

22. Murugesh K, Deepa S, Venkatesha D (2014) Multi drug resistant uropathogens in HIV: Are they a threat to community. Int J Scientific Study 2: 38-42.

23. lyang-Etoh PC, Udofia GC, Alaribe AA, Udonwa NE (2009) Asymptomatic bacteriuria in patients on ART in Calabar. J Med Sci 9: 270-275.

24. Philip PJ, John T, Sigrid K, Brandi L, Lowery HK (2013) Resistant Staphylococcus aureus colonization of the groin and risk of clinical infection among HIV infected adults. Emerging Infectious Diseases 19: 4.

25. von Eiff C, Becker K, Machka K, Stammer H, Peters G (2001) Nasal carriage as a source of Staphylococcus aureus bacteremia. Study Group. N Engl J Med 344: 11-16.

26. Bearman GM, Wenzel RP (2005) Bacteremias: A leading cause of death. Arch Med Res 36: 646-659.

27. Tumbarello M, Tacconelli E, Caponera S, Cauda R, Ortona L (1995) The impact of bacteraemia on HIV infection: Nine years' experience in a large Italian University Hospital. J Infect 31: 123-131.

28. Laupland KB, Church DL, Mucenski M, Sutherland LR, Davies HD (2007) Population-based study of the epidemiology of the risk factors for invasive Staphylococcus aureus infections complicated by bacteremia. Diagn Micobiol Infect Dis 187: 1452-1459.

29. Alemu A, Degnaw M, Alem M, Gizachew M (2013) Uropathogenic bacteria isolates and their antimicrobial susceptibility patterns among HIVIAIDS patients attending Gondar University Specialized Hospital Gondar. J Microbiol Res Rev 1: 42-51.

30. Adegoke AA, Tom Mvuyo, Okoh A, Steve J (2010) Studies on multiple antibiotic resistant bacteria isolated from surgical site infections. Scientific Research and Essays 5: 3876-3881. 